УДК: 7.032(37); 728.84; 904

ББК: 85.113(3)

A43

DOI: $10.18688 / \mathrm{aa} 199-1-14$

P. Gardelli

\title{
Reconstruction and Restoration Works at Villa Arianna in Stabia Prior to the Eruption of 79 A.D.
}

During the reign of Nero a seismic event of considerable intensity struck large areas of Campania, profoundly impacting its social and economic life even before the eruption of 79 A.D. ${ }^{1}$ This event ${ }^{2}$, widely documented by historical sources, epigraphic texts [26, pp. 140-141; 45] and figurative reliefs [1], is one of the few fixed points in the chronology of the history of Vesuvian sites. The event was reported by Tacitus (Annales 15.22.2) and in more detail by Seneca ( $\mathrm{Na}$ turales Quaestiones 6.1.1-10; 6.25.3; 6.30.4-5; 6.31.1-3). Although there is no general consensus on the exact date of the earthquake, which according to Tacitus appears to have taken place in 62 A.D., while Seneca dates it to the following year, the most widely accepted opinion today is based on the writings of the former author, namely that this event took place on February 5, 62 A.D. ${ }^{3}$

Seneca, unlike the more annalistic writing style of Tacitus, is the only one to deal with the earthquake of 62 A.D. in any detail and, although he does not appear to have been a direct witness to the event, his text is considered to be fairly reliable by the modern scientific community [37, p. 132].

According to the writings of Seneca, it is clear that the urban areas most affected by the earthquake were Pompeii, Herculaneum, Nuceria and Neapolis (N. Q. 6.1.1-2). The order in which the four names were reported in the text is understood not to be a random decision but rather evidence of the author's intention to highlight the difference in the scale of the damage, which was greater in Pompeii and Herculaneum but of lesser impact in the other two localities [37, p. 132].

For a long time there has been debate over the nature of the earthquake and the exact location of its epicenter. Given the considerable time span between the earthquake of 62 A.D. and the eruption of 79 A.D., part of the scientific community considers the earthquake to be a tectonic event that bore no relation to the volcanic eruption a few years later [37, p. 133; 48].

\footnotetext{
1 I would like to thank Prof. Dr. Massimo Osanna, Director of Parco Archeologico di Pompei, and Dr. Giovanna Bonifacio, Director of the site of Stabia, for their willingness to grant permission for new research. Special thanks to Dr. Vyacheslav Telminov and Sarah Livesey who provided the translation of this article into English, to Dr. Roberta Fonti of Technische Universität München for her technical advice on masonry structures and to Prof. Dr. Thomas Noble Howe, RAS Foundation General Coordinator for his invaluable assistance.

$2 \quad$ For a more detailed study of the social and economic history of Pompeii see $[3 ; 10$, pp. 169-187; 31; 33; 34 , pp. 211-234]; for the archaeological documentation see [16;35; 36; 43; 50].

3 The dating of Tacitus is given more credit than that of Seneca. Seneca's reference to the consuls of 63 A.D. in N.Q. 6.1.2 is generally considered to be an interpolation. On the controversial manuscript of the passage, see [29] stating that the interpolation of the consuls' names is probable, but not certain. On dating the earthquake at 63 A.D. see [47]. On its dating at 62 A.D. see [41].
} 
According to this theory, the origin of the earthquake should therefore be sought not in the Vesuvian area but rather, given the seismicity of Southern Italy, in the Apennine region.

However, other literary scholars take a completely different view. Indeed, many authors, who take into account only the data that comes from the sources, consider Pompeii to be the place most damaged by the earthquake, and so, in their opinion, the epicenter was near that city, supporting the view that the earthquake was of volcanic origin [37, p. 133].

Moreover, one should not exclude the hypothesis that one or more seismic events shocked the Campania region within a relatively short time period ${ }^{4}$.

Despite the absence of clear information in the ancient written sources, other minor earthquakes may have shocked the entire region. From 62 A.D. to 79 A.D. some ancient writers reported frequently recurring tremors in Campania. Seneca himself remembers that the entire Campania region was "numquam securam huius mali" (Sen., N. Q. 6.1.1-2), and in the second epistle to Tacitus, Pliny the Younger reports that in the days before the eruption there were many earthquakes that were ignored since they were a very common occurrence (Plin. Iun., Epistulae 6.20). Notably, there is a record of an earthquake striking Naples in 64 A.D., which entered official historic records because the emperor Nero was one of the protagonists of the event (Tac. Ann. 15.34.1; Suet., Nero 20,2).

It may seem rather strange that Stabiae and its territory are not listed by Seneca when he reports cities damaged by the earthquake in 62 A.D. Absence of explicit references should not be read as evidence of the absence of seismic activity in the Stabian area. Considering its proximity to the affected territories, it seems unlikely that the town of Stabiae was not damaged by the earthquake. This should rather be put down to the fact that the ancient historiographers in the $1^{\text {st }}$ century A.D. paid scant attention to a modestly sized town like Stabiae.

The archaeological investigations carried out since the 1950s have not only led to the rediscovery of ancient Stabia and brought new insights into the settlement dynamics of villas along the plateau of Varano between the Late Republic and The Early imperial period, but have also allowed archaeologists to document for the first time how this area was affected by the destructive events arising from the earthquake of 62 A.D. Until now, Villa San Marco is the only one of the three unearthed villas to have been part of a study focused on the effects of the earthquake on its walls and its decorative apparatus $[4 ; 44]$.

However, there is no such historiography regarding Villa Arianna and the Second Complex. Excavation campaigns conducted at Villa Arianna since 2010 [7;17; 18; 21;22; 30] have therefore provided a starting point and a number of useful findings from which to develop some theories about the existence of reconstruction works within the residential complex in the months and years that preceded the 79 A.D. eruption.

A good and often underestimated starting point for a study of this kind is unexpectedly contained in the $18^{\text {th }}$-century excavation reports. These reports generally provide very synthetic information about the discovery and removal of wall paintings, floor decorations and objects of various kinds, and they are of fundamental importance today for an accurate understanding of the provenance and context of the findings. Sometimes, however, from a more careful rereading between the lines of the excavation reports, it is also possible to gather valu- 


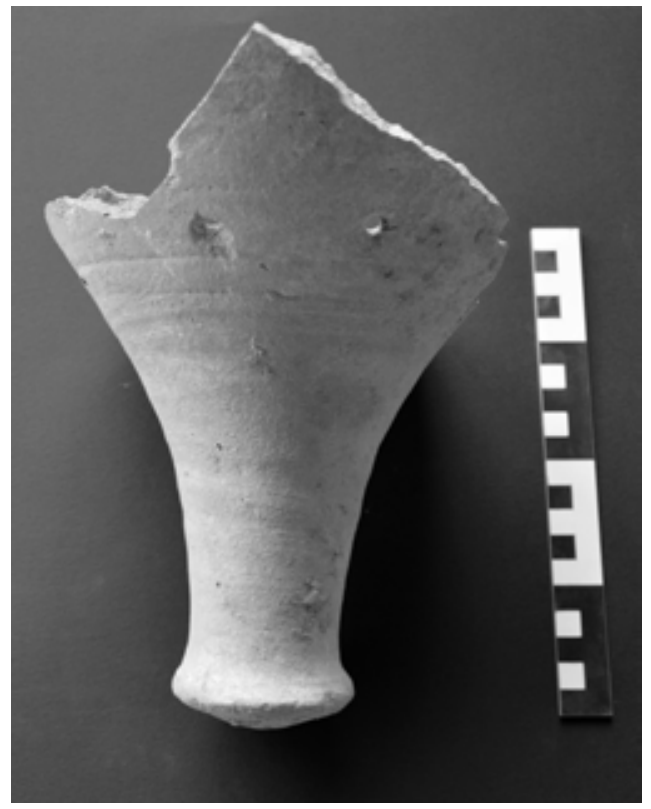

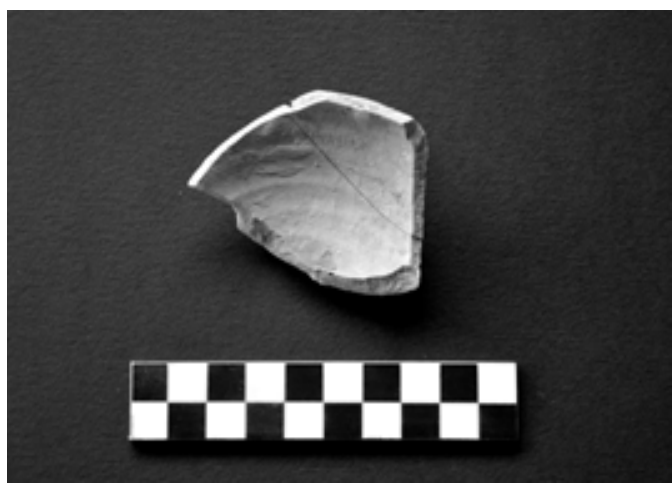

Fig. 2. Fragment of the terracotta bowl containing red pigment residues (C) Parco Archeologico di Pompei

Fig. 1. The lower portion of the amphora found in the heap of ancient materials (C) Parco Archeologico di Pompei

able information about the discovery of objects that in the eyes of the first excavators certainly appeared devoid of any value, not deserving the ruler's attention and therefore later lost or destroyed. Today, with a completely different methodological approach, these objects are crucial for a more accurate understanding of Villa Arianna. In this regard, it is also worth noting that on several occasions brief notes were recorded documenting the discovery of work tools typically used by masons and painters and of ceramic containers with pigments inside them. All these findings are unequivocal signs of works in progress in different areas of the villa in the moments that preceded the eruption ${ }^{5}$. For example, Roque Joaquín de Alcubierre reported the discovery of a "bacía con color á dentro" ("vessel with color inside") on September 14, 1755, within the area which Karl Weber's plan referred to as room W2, today located in the part of the villa still to be excavated [46, p. 43], thereby inadvertently providing valuable information about the presence of a vessel containing pigments. Another discovery nearby, this time of a small compass, was recorded on November 8,1755 , within room W4, which is currently also still buried underground [46, p. 44]. A few years later, a "crocciolo di terra con colore rosso dentro" ("clay vessel with red color inside") [46, p. 109] was found on October 31, 1759, upon the relaunching of excavations in this area of Villa Arianna, also within room W4. The following objects were also found on the same day: a "vasetto fino colorito di giallo dentro" ("jar with yellow color inside") [Note 46 at the margin of Table IV]; a weight made of metal, part of a

5 In the excavation reports in Pompeii specific annotations relating to possible evidence of restoration works before the eruption began to be recorded in the period immediately preceding the Unification of Italy. Fiorelli and Sogliano show that they have already gained full scientific awareness of the matter. Spinazzola leaves lime piles in situ as they were found. Maiuri gives [36] a fairly detailed picture of the works that were taking place in various houses and indications of a large number of buildings in which the restoration work, started just before 79 A.D., was still ongoing in that year [49, p. 35 note 7]. 
plumb rule; a "cucchiara da muratori" ("a mason's trowel"); and the second "compasso patito" ("a damaged compass") [46, p. 109]. A second trowel was found on April 3, 1760, in what today is referred to as room 10 [46, p. 124]. The following year, on 21 and 22 August, 1761, there was a note about the discovery of "un stecco di ferro per uso de" stuccatori" ("an iron rod of the type used by plasterers") and "una cuchara de fabricador de hierro de un palmo grande" ("an iron mason's trowel of the size of a palm") in an undefined room, probably close to the great peristyle $(\mathrm{H})$ [46, pp. 155-156]. Finally, "una cucchiara di fabbricatore rotta" ("a broken mason's trowel") appears to have been found a few weeks later on October 2, 1761, near the atrium (24) [46, p. 159].

It is important to point out that these findings only relate to tools and equipment for plaster work and the repurposing of architectonical surfaces rather than for structural renovations.

It is well known that masonry constructions are very sensitive to seismic activity, which results in early cracks running across the entire width of the wall. Therefore, a major reconstruction of parts of the masonry was necessary after an earthquake. On the one hand, this prevented the structures from further damage, but on the other hand, this was responsible for a lack of structural integrity, which is clearly visible when investigating such walls. In particular, if impacted by a horizontal stress - such as of the type produced by an earthquake - cracks would appear in a specific pattern clearly distinguishable in the walls [23]. In this light, the results of an investigation of the pictorial surfaces, together with the evidence of the ultimate phase of a repurposing work, can be interpreted as a change of use of the villa or equally as a post-earthquake reconstruction of its structures.

Other interesting findings also hint at the fact that there were works in progress inside the villa, more precisely in the great peristyle area. In fact, on February 21, 1778, eighteen ollae pertusae were brought to light inside two unidentified rooms close to a large porticoed space [46, pp. 263-264]. As is generally known, these are ceramic pots [39, p. 170], usually with four holes, used for agricultural or gardening purposes such as transplanting small ornamental plants, sowing or transporting tree species over long distances (Plin., N.H. 12.16; 17.64; Cato, De Agricultura 52.133). The discovery of eighteen vessels inside two rooms close to the porticoed area might therefore further confirm the fact that, in the days and weeks preceding the eruption, some renovation work was carried out in the large space that served as a garden. It follows that the pots might have been temporarily placed inside the two rooms in the course of such maintenance works. From this perspective, the metal remains found on the surface of the floor of the ancient garden seventeen years earlier, in the period between 10 and 24 July, 1761 , which were interpreted by Weber as belonging to a small cart, could actually be the only surviving parts of a cart used in this area for carrying out maintenance work in the garden [20, p. 17].

Thus it can be stated that there are numerous details present in the excavation reports of the $18^{\text {th }}$ century that more or less explicitly provide useful evidence in support of this hypothesis. The archaeological evidence present in situ and the data that has emerged during the excavation campaigns in the last ten years is even more abundant.

During the last excavation campaign of 2010-2013, key observations were made based on the historical damage incurred by the masonry structures of the thermal quarter. Here, it was seen that the walls on one side did not have one of the external wythes. Additionally, the par- 
allel walls showed similar signs of damage, which had resulted at times in the full reconstruction of parts of the masonry, displaying different and newer techniques of execution. Missing wythes and partial reconstructions of top parts of walls are commonly associated by structural engineers with post-earthquake out-of-plane damage [23]. Notably, in the structure of the tepidarium (31) in Villa Arianna, it was possible to observe that the original floor had been restored in ancient times [19, p. 441, pp. 446-447, fig. 5-6]. The additional work is running sidelong to the missing wythes. Here, an unusual layering of the plaster can also be seen; this has been directly applied over the opus caementicium on the walls without any reconstruction of the missing wythe. This observation leads us to two legitimate assumptions: 1. no structural works were executed, which might explain the absence of special masonry tools; 2 . the need for normality after a traumatic event prompted a quick method of reconstruction that ignored the basic rules of Roman building workmanship.

However, it is important to note that the thickness of a wall is a crucial parameter for the stability of historic masonry constructions in situations of horizontal stress [9]. Thus, it can be inferred that the Romans designed masonry constructions to be overdimensioned. In fact, there is a direct correlation between the thickness of a wall and its ability to withstand earthquakes and out-of-plane displacements. This ratio, if not respected, might lead to a collapse of masonry constructions [15]. Additionally, the method of building walls here was opus quasireticulatum. It is, therefore, apparent that the walls did not lack wythes originally; the second external wythe was vital for their construction.

Cleaning works carried out in the summer of 2017 inside room 71 were certainly instrumental in uncovering new evidence of construction activities in this area of Villa Arianna [21]. As of now, room 71 has not yet been completely unearthed and so its total dimensions (probably more than $28 \mathrm{~m}$ ), as well as its planimetric extension in the still covered SE portion, are unknown. In the excavated area, the layout of room 71 is significantly elongated. At the current state of research, the exact positioning of the main entrance to room 71 is not yet known. Along the NE wall, near the $\mathrm{N}$ corner and on top of three steps, there is a door opening 1,42 m wide, which was certainly no longer in use in the last phase of Villa Arianna since it is blocked by a wall of opus incertum.

Regarding the possible purpose of room 71, it might have served as a cryptoporticus in the period prior to the renovation work, given its considerable size and very elongated layout - a long passageway located close to the entrance and built in order to connect the southern, still underground, part of the villa with the porticoed space (86) and the bathing facilities $(06,30$, $31,85)$. However, given the current state of research, it is more challenging to determine what the function of the room would have been once the construction work had been concluded. Nevertheless, as will be read soon, there is evidence that it may have been converted from a cryptoporticus to a service or storage area.

During these works, a layer consisting entirely of waste materials was removed from the NW area of room 71 . These materials were used to backfill the area after the $18^{\text {th }}$-century digging. Within the backfill layer, two notable accumulations of ancient materials have been identified.

In the pile of materials documented close to the SE wall, deserves a mention the discovery of a lower portion of an amphora, which contained a considerable quantity of lime mixed with fine sand (Fig 1). The presence of two small holes on the walls of the amphora and its contents 
unambiguously prove that it was reused as a container for building materials. Nearby there was another discovery of the lower portions of two other terracotta containers of an uncertain type inside which there were some hardened deposits of clay and lime dust. Another discovery worth mentioning is that of some fragments of two or more terracotta containers, presumably vessels or bowls: light deposits of green and red pigments are still visible on their inner walls (Fig. 2). These discoveries appear to confirm that renovation works were in progress at Villa Arianna, or at least in this particular area of the complex, in the period immediately preceding its destruction.

Out of a large quantity of materials found in the $18^{\text {th }}$-century backfill layer, the discovery of mosaic fragments should be mentioned, coming from one or more floors, datable to between the Third and the Fourth Pompeian Style. These suggest that works were also being carried out on some of the villa's mosaics [22].

One such group consists of fragments of one or more floors with a background of black tesserae and marble inserts, which are unevenly covered by a rich layer of mortar. The coating may have been a layer of liquid mortar applied in order to fill cavities between the tiles on completion of works carried out on one or more of the villa's floors. Once the joints were hardened and filled, the mortar layer would then be removed to reveal the original floor surface ${ }^{6}$.

Excavations have also brought to light numerous portions of monochrome mosaic tiles, presumably black, framed by strips of contrasting color, with a rather unusual black and white repainted layer. The traces of repainting reproduce the coloration of the underlying tesserae: one or more white strips on a black background. The use of black and white painted floor tiles is not very common in the Vesuvian area, although black colored tiles appear on the thresholds of the Corinthian oecus of the Casa di Meleagro in Pompeii (VI.9.2-13), datable to the period after the 62 A.D. earthquake [24, p. 158]. Fiorelli gives the following account: "De' musaici variati si osservano fra glintercolunnj, e sono curiosi per la circostanza, che il nero non è il colore naturale della pietra o del marmo ma vi è stato dato col pennello nel formarsene il disegno" ("Various mosaics are observed in the intercolumniation, which are curious because the black color is not the natural tint of the stone or marble, but was painted with a brush") [14, p. 239].

There is a white monochrome floor bordered by peripheral linear cornices, almost completely overpainted with black and white, at Villa Sora in Torre del Greco in one of its recently excavated rooms in the living quarters between oecus 2 and corridor 7 [25, pp. 107-128; 42, pp. 267-269]. Both the mosaic floors in Pompeii and Torre del Greco can be dated to the period after the 62 A.D. earthquake. Considering the scarcity of material at our disposal, it is not easy to put forward hypotheses to explain the presence of the thin repainted layer on the floor at Villa Arianna. However, we should not exclude the possibility that the portions discovered during the excavations inside room 71 are dated to the same period of time, between 62 A.D. and 79 A.D., and are related to renovation or reconstruction works on some of the floors at Villa Arianna. The use of color might have been a technical solution to

\footnotetext{
The very first notification about the existence of a black and white floor covered with mortar was provided in the $18^{\text {th }}$-century excavation journals, in which, on January 17,1761 , the following was registered: "los cuadretos blancos y negros son cubiertos de yeso" [46, p. 145]. The correlation between the layer of mortar still present on the mosaic surface and the possible state of incompletion of the floors had already been advanced by Libero d'Orsi [12, pp. 56, 130].
}

6 
make cavities between the tesserae less visible, while also bringing more uniformity to the design [8, p. 488].

In a famous passage, Seneca provides further confirmation of the fact that the earthquake caused damage not only to the wall structures but also to the mosaic floors of many buildings: "uidisse se affirmat in balneo tessellas quibus solum erat stratum alteram ab altera separari iterumque committi et aquam modo recipi in commissuras pauimento recedente, modo compresso bullire et elidi" (Sen., N. Q. 31.3).

It is therefore unsurprising that at Villa Arianna, as well as in many other buildings on the four sites in the Vesuvian area, we can see a large number of floors that had already been patched in antiquity, or on which works were still underway in the days before the eruption [44].

Another discovery confirms this. The extension of the cleaning operations towards the SE portion of room 71 has allowed us to document the collapse layer originating from a portion of the room's ceiling. In the collapse layer numerous pieces of plaster are still visible, with traces of the thatch used in the ceiling to make it lighter, and some fragments of roof tiles. A floor has been identified below the remains of the ceiling, which is made of simple tamped lime with a very irregular surface. During the cleaning operation, it was possible to see a coarsely ground pile of bricks between the collapse layer of the ceiling and the floor. This discovery is certainly of interest; in fact, if it relates to the tamped lime that covers this part of room 71, it suggests that a new cementitious terracotta-based floor was under construction at the time of the eruption.

The floor in room 71 is not the only example of an unfinished floor at Villa Arianna. In fact, in the unearthed part of the housing complex two other floors of considerable size, consisting of a simple rammed earth, are also visible.

The first is that of the great peristyle $(\mathrm{H})$, first identified in the $18^{\text {th }}$ century by Weber, and later investigated again by La Vega [46, p. 155]. On August 14, 1761, Weber writes a short message reporting the discovery of "un cortillo centenado con 7 pilares al rededor, las murallas entonicadas de blanco con el pavimento de tierra" ("a court with seven pillars around it, the walls plastered in white with an earthen floor"). A few years later, in the period between December 1777 and June 1778, La Vega conducted a new search campaign in the peristyle area, during which several sections of the floor "di terra ben battuta" ("of well beaten earth") were discovered in several other places [20, pp. 18-19; 46, p. 315]. Thanks to the notes of Weber and La Vega, it is clear that at the time of their excavations there was simply rammed earth instead of floors in this porticoed space. The absence of the floor in this part of the villa should not therefore be attributed to the $18^{\text {th }}$-century looting but rather to the fact that it was actually absent at the time of the eruption. The second example of tamped ground was brought to light recently during the excavation works in the area of the square peristyle (91) in the summer of 2010. Here the tamped ground was documented along the whole NW side of the peristyle and along the short, excavated portion of the SW side. The NE and SE sides, as well as a good portion of the SW side, are currently still underground. The peristyle and the neighboring area were investigated as early as the $18^{\text {th }}$ century, more precisely from January 1758 [46, pp. 72-76]. Although the Bourbon excavation reports offer a very detailed description of all the archaeological evidence in situ and the materials found during the works, no mention is made of what the floor of the porticoed area looked 
like and whether it was detached by the excavators. The silence of the $18^{\text {th }}$-century sources on this point therefore appears to suggest the total absence of a floor covering this area of the villa, which once again would indicate that the floor was in a state of incompletion at the time of the disaster?

A slightly different example is that of two other floors and marble wall decorations that, in my opinion, deserve a separate mention. On December 6, 1759, two workers, Caruso and de Çiria, reported in a note that they had identified a room that was covered by "tunica blanca y el pavimento de mauton pisado, y era guarnecida de marmol, ha estado esguarnida de los antiguos" " white plaster and a cocciopesto floor, and decorated with marble, which had already been looted by the ancients") [46, p. 113]. The floor of this room still showed traces of the marble slabs that had already been detached in ancient times. Since in those days there were excavations in several rooms in the bathing area, it can be supposed with some confidence that the room in question is one of the two rooms between the tepidarium and the caldarium ${ }^{8}$. As confirmed by the latest excavations, both rooms lack marble slabs on the floor as well as on the lower register of the walls. A similar situation has been documented in the atrium (24) of the villa where, at the time of the first excavations, both Weber and Alcubierre reported on October 24, 1761, in two separate notes, that in the room they were digging, the walls and two small pedestals (an altar and a podium of a lararium of Villa Arianna) must have originally had a marble decoration, which at the time of the excavation was no longer present, or rather only in small quantities, having already been removed " $d e$ los antiguos" ("by the ancients") [6, p. 96; 46, p. 162].

In order to further confirm that the Bourbon workers were not responsible for the detachment of the marble slabs in both the bathing facilities and in the atrium (24), one can say with certainty that on many other occasions when the excavators came across vast surfaces decorated with opus sectile - in all excavated parts of room R at Villa Arianna [46, pp. 149-150] and in room 13 of the Second Complex [46, pp. 231-232] - these excavations were covered by extremely detailed reports containing information on the phases of work, measurements, quantities and types of stone materials removed.

It may be logical to assume at first that the marble slabs, as already highlighted by the $18^{\text {th }}$-century excavators, had been removed by unknown looters at an unspecified time following the eruption. However, a brief note in the $18^{\text {th }}$-century excavation reports, which in the past was often overlooked, hints at the presence of maintenance works on the marble surfaces inside the villa. On August 29, 1761, Weber reported that he had identified in an unspecified room, probably near the atrium (24), a large pile of slabs and fragments of marble of various types, which he described in great detail: "dos cofanos de pedacillos de Africano, Porta santa, jalo antiguo; tres cofanos de rojo frisili antiguo, dos cofanos de frisili de Sarabeza y dos cofanos $1 / 2$ de rojo antiguo, y pedazos de cornis de marmol blanco" "Two caissons full of pieces of Africano, Porta Santa, giallo antico; three caissons of fragments of rosso antico, two caissons of fragments of Seravezza marble and two caissons and half

\footnotetext{
7 The same incompleteness of the floor had been documented in the upper peristyle 1-2 of Villa San Marco, see [5, p. 52].

8 It is likely that the room the workers referred to was the caldarium since it is the only room in the bath area that has some surviving traces of raw plaster of white color.
} 


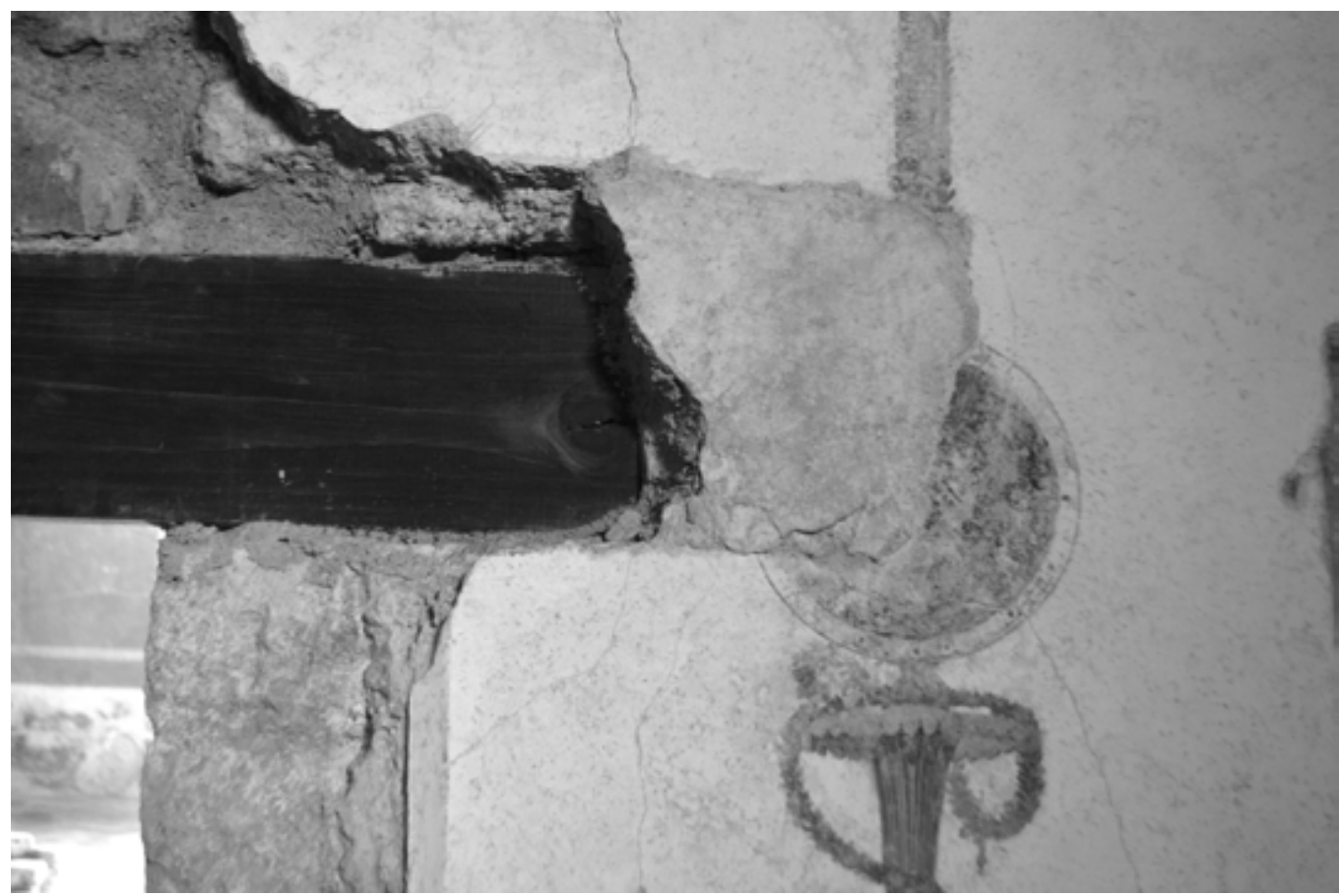

Fig. 3. The cuts and the stucco patch made in ancient times for the substitution of the lintel in room 89 (c) Parco Archeologico di Pompei

of rosso antico, and portions of white marble frames") [46, p. 156]. Although this finding does not prove beyond doubt that reconstruction works were in progress in the atrium (24) or in the bathing area at the time of the eruption, in my opinion, it has some importance because it at least appears to indicate that some works were being carried out on the marble decorations in some unspecified rooms of the villa.

While waiting for the completion of an in-depth study aimed at analyzing the wall structures, even a simple observation of the plastered surfaces reveals that some reconstruction works were almost certainly performed in various parts of the villa after the 62 A.D. earthquake.

Some interesting data in this respect emerged during the excavation conducted from 2010 to 2013 in the area of the bathing facilities and the surrounding rooms $[17 ; 18]$. The investigation demonstrated that the bathing quarters were accessed through a long corridor (87), which begins near the W corner of the square peristyle (91) and ends further south in a large open space in front of the bathing quarters. On the NW wall of the corridor there are two doorways. The first leads into a biclinium (89) with red walls and two alcoves: one painted yellow, facing $\mathrm{NE}$, and another painted white, facing NW. The second doorway leads into a large porticoed space (86) situated just in front of the entrance to the bathing quarters.

In the center of room 86 is a green space surrounded by a small colonnaded portico made up of circular columns covered with red painted plaster: four on the long NW and SE sides, three on the short SW side, and three semi-columns on the NE side. Three semi-columns support a false overhanging porticoed structure under a short roof. The false porticoed structure 


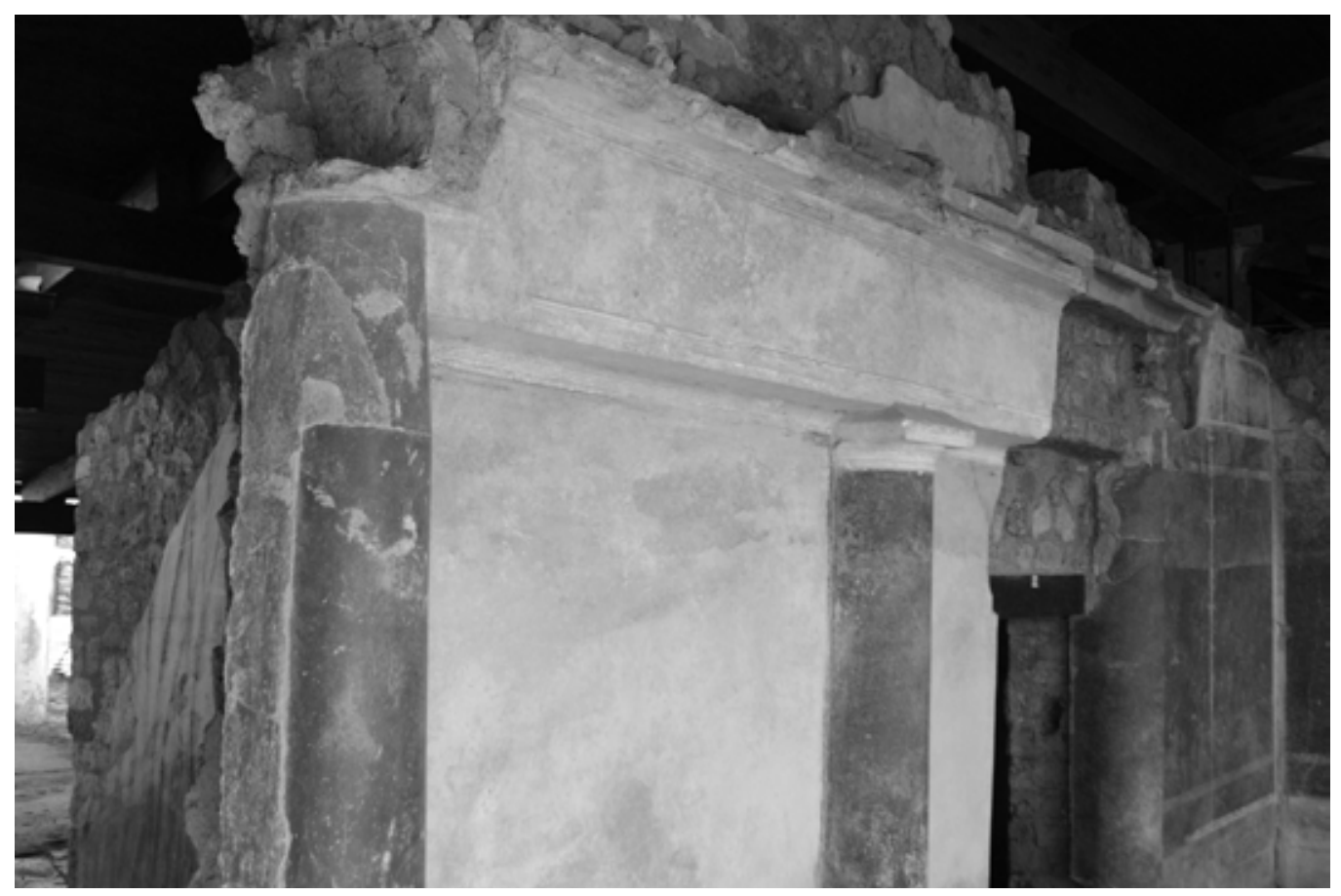

Fig. 4. The cuts and the red stucco reconstructions visible on the false porticoed structure in room 86 (C) Parco Archeologico di Pompei

was built along the wall that separates room 86 from biclinium 89 . At the center of the wall there is a window opening through which there is a garden view from biclinium 89. It was along this wall that several interesting discoveries were made that lead to the hypothesis of some post-earthquake reconstruction works. Along the dividing wall on the inside of biclinium 89 there is a decorative motif in the Late Third Pompeian Style: a candleholder at the top of which there is an oscillum from which a vegetal garland descends. The cleaning works on this wall have made it possible to identify the presence of a white stucco patch $(0,21 \times 0,20 \mathrm{~m})$, made in antiquity, which very crudely cuts across the wall decoration (Fig. 3). The patch, which is exactly in front of one of the two spaces inside which the window architrave was placed, should, in my opinion, be attributed to reconstruction works carried out on the wall after the 62 A.D. earthquake. During seismic events in particular, parts of the timber beams above windows are easily displaced on account of their relatively light weight and the loss of connection between the timber and the supporting walls (anchors). In fact, when subjected to significant acceleration, those beams can stay in place, albeit not in their original position, because of the friction between the surface of the timber and the wall 9 .

Still on the same wall, but on the opposite side facing the porticoed space 86 , one can clearly see more evidence of restoration works. The false porticoed structure that decorates the partition wall has two distinct cuts in the red plaster on two external columns, 1,90 and 
2,00 $\mathrm{m}$ above the floor. Above the cuts the plaster and the red pigments used for the decoration of the upper part of the wall are completely different from those visible on the lower portion of the columns. The cuts and the difference in quality of the plaster and pigments allow us to hypothesize that the upper portion of the false porticoed structure was completely rebuilt during some works carried out on this wall, while the lower part was not destroyed by the earthquake but was reused (Fig. 4).

Such damage scenario goes with the typical out-of-plane damage that occurs when a masonry facade overturns around the pivot points at its base as a result of an earthquake. Depending on the type of intermediate floors and the direction of seismic action, local failure mechanisms can occur with different shape outlines ranging from a triangular portion of masonry to a square shaped block rigidly overturning at cracks [23]. Another interesting element is visible along the external side of a column on the left of the false portico. Indeed, here the excavators documented a rough patch, measuring about $1,00 \times 0,15 \mathrm{~m}$, of very poor red plaster, which was used to consolidate the reapplied layer in the upper part of the column.

The excavation works have also made it possible to completely unearth the long corridor 87 . The two walls of the corridor have a very simple and linear tripartite decorative scheme in the Third Style. The cleaning works have allowed us to document a sudden interruption in the wall decoration in the last section of the SE wall of corridor 87. In fact, about $1,20 \mathrm{~m}$ away from the short wall at the end of corridor 87 in the SW direction, one can clearly see the beginning of white plasterwork of very poor quality, probably used to rectify damage to the previous decoration. This layer of white plaster is also visible on the short wall at the end of corridor 87 in the SW direction. In my opinion, given the poor quality of the decoration, it can be stated that temporary plaster was also applied to this wall in the aftermath of some disastrous event that struck the villa at some point before the eruption.

Another interesting detail is the fact that the short wall at the end of the corridor in the SW direction is the same wall that was built in opus incertum in order to block the doorway connecting corridor 87 with the hypothetical cryptoporticus 71 . The construction of this wall can be interpreted in two different ways. The first and most obvious interpretation is that the wall was constructed to reorganize room 71, possibly with a consequent change in the use of this space: no longer a cryptoporticus but a service or storage area. It must be noted, however, that the rapid method of construction, the modest use of binding material, and the presence of a layer of poor quality white plaster on only one of the two sides, that facing corridor 87 , all appear to indicate the very temporary nature of the structure. The second hypothesis is that this was a raised wall, the sole purpose of which was to prohibit access to a construction site in which works were still ongoing; at the end of the works it would have been demolished to restore the connection between the two rooms.

Other evidence of the reconstruction of plastered surfaces, dated to the seventeen years period between 62 A.D. and 79 A.D., is visible in other parts of the villa. During some excavations in 1992, room 79 was identified, a residential room in the area of the villa located between the square peristyle (91) and the ramp to the sea (76). At the time of the excavation, room 79 was decorated with a refined floor with a black and white geometric mosaic, while the walls were covered with a simple base coat. The presence of the floor decoration 


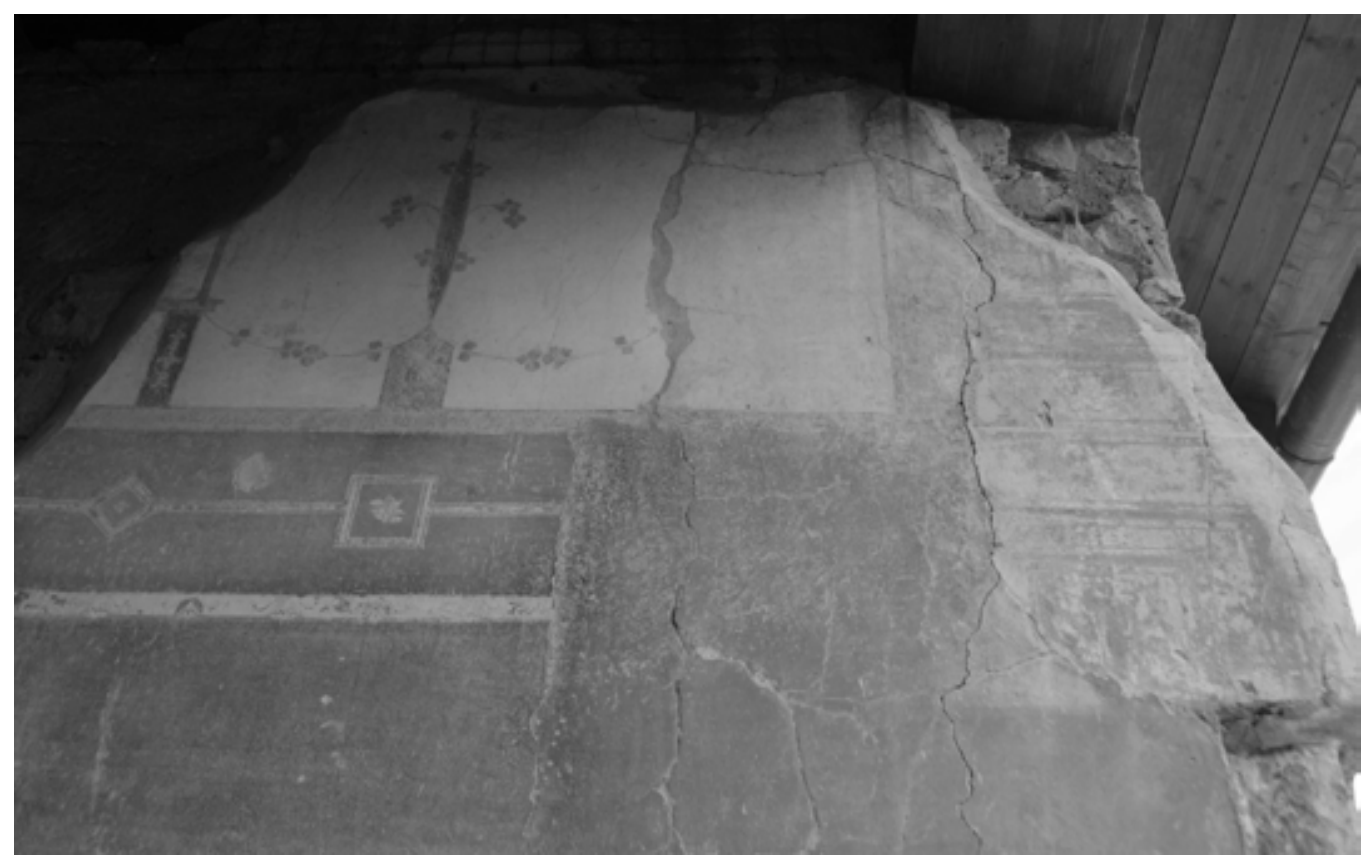

Fig. 5. The cut in the Third Style wall decoration of the NE wall of vestibulum 46 and in the center the poor quality plaster patch (C) Parco Archeologico di Pompei

appears to confirm the residential purpose of the room at the time of the eruption, while the archeologists understood the lack of wall paintings to be a clear indication that the entire room was about to receive a new wall decoration, not yet started at the time of the eruption [40, pp. 58-59].

Another technical incongruity that could be explained to be part of reconstruction works that took place after seismic events before the eruption is visible inside the vestibulum (46) of Villa Arianna. Two walls of the vestibulum have a very simple tripartite decorative scheme that can be ascribed to the Third Style. The socle is black embellished by a square element set diagonally with a floral motif in the center; the middle part has a red monochrome panel surmounted by a light colored embroidered border, while the upper register (preserved only on the NE wall) has a richer decorative scheme on a white background in which one can see some stylized architectural elements decorated with garlands. In the upper portion of the NE wall, near the corner, there are remains of a motif against a black background with polychromy [6, p. 92]. The decoration of both walls has been integrated with an inelegant frescoed surface. More specifically, these are two patch works which were clearly an attempt to restore damaged pictorial surfaces, returning them to the same tripartite design but achieving rough results because of the quality of the pigments and the lack of technical skill of the painters involved (Fig. 5). The patch on the NE wall is 3,34 $\mathrm{m}$ high and between 0,15 and $0,64 \mathrm{~m}$ wide; the one on the $\mathrm{SW}$ wall measures $3,03 \mathrm{~m}$ in height and $0,56 \mathrm{~m}$ in width.

Another small piece of evidence that there were works in progress in the villa is visible within room $\mathrm{U}$. This is a partially excavated porticoed room. The wall decoration of the room 
is made up of a white background with the socle part standing on a low plinth, adorned by a red thread dividing it into narrow panels decorated with a stylized lotus flower. The panels are crossed horizontally by embroidered bands. The top of the socle is bordered by a yellow ocher band with red threads, on top of which slender, vegetal chandeliers adorn the central panels, framed by embroidered borders [6, p. 163]. The NE side of room $U$ consists of a colonnade formed by a pillar and two leaning semi-columns, a column with a smooth shaft and an angular pillar covered with rough plaster [6, p. 162]. Here too, the presence of rough plaster could suggest, as in other areas of the villa, the presence of wall paintings not yet completed at the time of the eruption.

Finally, I would like to say a few words about some interesting findings documented in several parts of Villa Arianna in recent years. The cleaning operations carried out in 2010-2013 made it possible to identify, on the two masonry benches located in the external space in front of room 86, two complex drawings made up of intersecting circles and arches deeply cut into the stucco using a compass. A very similar design, engraved on one of the walls of room 71, had already been identified during excavations in 1992 [6, p. 116; 40, pp. 54, 56]. Separate isolated circles, always made with a compass, have been found in several parts of the villa: a single circle and two concentric circles have been documented along the SE wall of room 81; on the NE wall of the same room two more concentric circles, crossed by two crosses and $\mathrm{X}$ signs, are visible; along the SW wall of room 38 two single circles are visible; another single circle has been identified along the SE wall of corridor 88; two circles have been documented on the SE pillar of room U; along the SW wall of square peristyle 91, close to the entrance of corridor 87 , during the last excavations a circle sign has been identified, with inner arches forming petals, made with a compass ${ }^{10}$. It is hard to find an explanation for these symbols. Circles of this type could be interpreted as lessons given to children about the fundamentals of geometry. The fact that lessons were organized for some of the inhabitants of the villas has also been confirmed by the discovery of graffiti in which one can see graphic proof of writing and alphabet exercises.

However, the discovery of circles of this type could allow an alternative interpretation which, in my opinion, is more realistic. The numerous circles could be understood not so much as geometry exercises by pupils but rather as drawings or technical drawings by painters or architects on plastered surfaces in a damaged state or pending reconstruction.

This would once again indicate that work was taking place inside the villa. To confirm this second hypothesis, it is worth quoting a very similar discovery from the temple of Apollo at Didyma: a drawing made up of a rosette with six white circles on a red background was found in the adyton's socle on a stone wall dated 250 B.C. [11, p. 78, fig. 8; 27, p. 103, fig. 4]. The central circle is the point of intersection of the other 6 circles; this composition of circles makes this drawing very similar to the one found in room 71 in 1992 (Fig. 6). This drawing, together with other preparatory drawings engraved on the walls of the entire inner courtyard and pronaos of Didymaion, have been recognized by various authors as representations of along the $\mathrm{S}$ wall of the public road outside the villa; in Pompeii similar circles on white plaster have been found in Casa dei Dioscuri (VI.9.6) in room 13, S wall, W side of doorway; and on the outer wall of the Casa dei Ceii (I.6.15). 

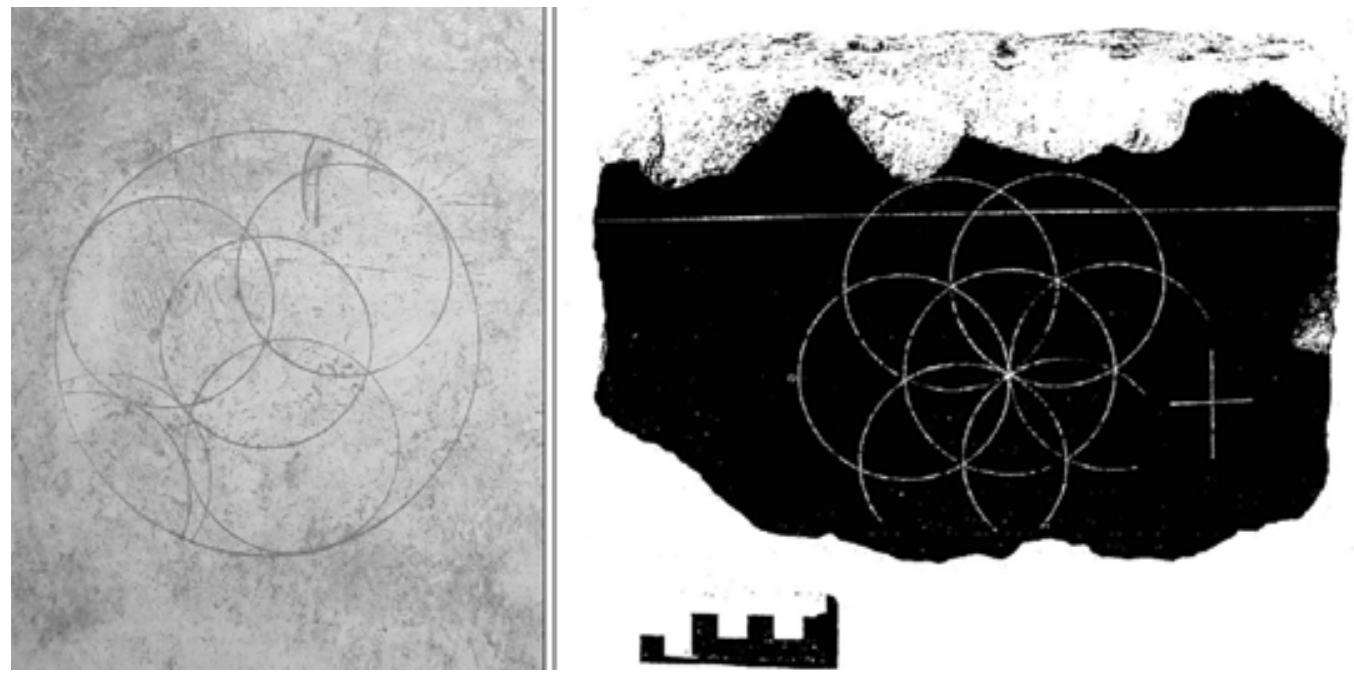

Fig. 6. On the right, the figure with circles found in room 71 in Villa Arianna (C) Parco Archeologico di Pompei; on the left, the rosette discovered in the temple of Apollo in Didyma (C) Corso A., Il disegno nell'architettura antica, Venezia, Marsilio Editori Publ., 2018 [11, p. 78, fig. 8]

specific architectural structures [11, pp. 53-54]. The three complex figures and the numerous single circles found at Villa Arianna could therefore constitute further evidence of works in progress in some rooms of the villa.

\section{Final remarks}

The overall conclusion that emerges from this work of synthesis between the historic records and the data coming directly from observation of the archaeological remains is that the residential complex in question experienced works of reconstruction and restoration in many of its areas in the period preceding the 79 A.D. eruption. Accordingly, not only was the villa not abandoned in the aftermath of the 62 A.D. earthquake, but, as well as being the object of restoration works, it was without a doubt maintained and taken care of. In my opinion, the villa remained functional, even if only partially, as appears to be confirmed by the discovery of some skeletons and some valuables in the area of the square peristyle (91) $[46, p p .68,79]$. However, some of the renovation works appear not to have been intended to maintain the same level of artistry of the interior decoration of the Julio-Claudian age and the early Neronian age. A reduction in quality, in terms of the materials used and the technical solutions adopted, was documented in many parts of the villa. There is no apparent explanation for the poor quality of these works in a building of such importance. In fact, this lack of care can only be rationalized if we consider that between 62 and 79 A.D. frequent seismic events, and probably also landslides, systematically caused damage to the villa, which had to be repeatedly repaired and so the aesthetic appearance became of secondary importance. The possibility cannot even be excluded that some of the renovation works were the result of a change of use of certain areas of the villa in the time period following the earthquake. 


\section{References}

1. Adam J. P. Il terremoto rappresentato: i bassorilievi di Pompei. Guidoboni E. (ed.). I terremoti prima del Mille in Italia e nell'area mediterranea: storia, archeologia, sismologia. Bologna, ING-SGA Publ., 1989, pp. 168-171 (in Italian).

2. Adam J. P. Osservazioni tecniche sugli effetti del terremoto di Pompei del 62 d.C. Guidoboni E. (ed.). I terremoti prima del Mille in Italia e nell'area mediterranea: storia, archeologia, sismologia. Bologna, ING-SGA Publ., 1989, pp. 460-474 (in Italian).

3. Andreau J. Histoire des séismes et histoire économique, le tremblement de terre de Pompéi (62 ap. J.C.). Annales. Économies, Sociétés, Civilisations, 1973, 28, no. 2, pp. 369-395.

4. Barbet A.; Blanc N.; Eristov H. Quelques problèmes chronologiques: à propos de la villa S. Marco à Stabies. Fröhlich T.; Jacobelli L. (eds.). Archäologie und Seismologie: la regione vesuviana dal 62 al 79 d.C.: problemi archeologici e sismologici. Colloquium, Boscoreale, 26-27 November 1993. München, Biering \& Brinkmann Publ., 1995, pp. 105-114 (in French).

5. Barbet A.; Miniero P. (eds.). La villa San Marco a Stabia. Napoli; Roma; Pompei, Centre Jean Bérard, École Française de Rome, Soprintendenza Archeologica di Pompei, 1999. 412 p. (in Italian).

6. Bonifacio G.; Sodo A. M. Stabiae, Guida archeologica alle Ville. Castellammare di Stabia, Nicola Longobardi Editore Publ., 2001. 216 p. (in Italian).

7. Butyagin A. Fresco Fragments from Villa Arianna Excavated by Expedition of the State Hermitage: Art as a Mass Archeological Material. Maltseva S. V. Stanyukovich-Denisova E. Yu.; Zakharova A. V. (eds.). Actual Problems of Theory and History of Art: Collection of articles, vol. 5. St. Petersburg, NP-Print Publ., 2015, pp. 160-168. Available at: http://dx.doi.org/10.18688/aa155-1-15 (accessed 20 June 2019).

8. Bueno M.; A. Lugari A. Per una definizione della cultura musiva di Aquileia: schemi geometrici e tecniche esecutive nelle prassi di bottega della prima età imperiale. Angelelli C. (ed.). Atti del XIX Colloquio dell'Associazione Italiana per lo Studio e la Conservazione del Mosaico. Isernia, 13-16 marzo 2013. Tivoli, Edizioni Scripta Manent Publ., 2014, pp. 487-496 (in Italian).

9. Ceradini V. Modellazione e sperimentazione per lo studio della struttura muraria storica, Doctoral thesis in History of Sciences and Building Techniques. Rome, Università La Sapienza, 1992 (in Italian).

10. Chiavia C. Programmata. Manifesti elettorali nella colonia romana di Pompei. Torino, Silvio Zamorani Editore Publ., 2002. 414 p. (in Italian).

11. Corso A. Il disegno nell'architettura antica. Collana del Centro Studi Vitruviani, no. 4. Venezia, Marsilio Editori Publ., 2018. 208 p. (in Italian).

12. d'Orsi L. Gli scavi di Stabiae. Giornale di scavo. Ministero per i Beni Culturali ed Ambientali, Soprintendenza Archeologica di Pompei, Monografie, vol. 11. Castellammare di Stabia, Nicola Longobardi Editore Publ., 1996. 526 p. (in Italian).

13. De Vivo A. Le parole della scienza. Sul trattato De Terrae Motu di Seneca. Collana: Storia e Scienza della Terra. Salerno, Laveglia Publ., 1992. 121 p. (in Italian).

14. Fiorelli G. Pompeianarum Antiquitatum Historia, vol. 2. Napoli, 1860-1864. 688 p. (in Italian).

15. Fonti R.; Borri A.; Barthel R.; Candela M.; Formisano A. Rubble Masonry Response under Cyclic Actions: Experimental Tests and Theoretical Models. International Journal of Masonry Research and Innovation, 2017, vol. 2, no. 1, pp. 30-60.

16. Fröhlich T.; Jacobelli L. (eds.). Archäologie und Seismologie: la regione vesuviana dal 62 al 79 d.C.: problemi archeologici e sismologici, Colloquium, Boscoreale, 26-27 November 1993. München, Biering \& Brinkmann Publ., 1995. 219 p. (in Italian and German).

17. Gardelli P.; Butyagin A.; Chistov D.; Ershova A.; Fiore I. Relazione preliminare sulle due campagne di scavo, restauro e rilievo 2010 e 2011 promosse dal Museo Statale Ermitage / Fondazione RAS presso il sito di Villa Arianna a Stabiae. Rivista di Studi Pompeiani, XXII, 2011. Roma, L'Erma di Bretschneider Publ., 2013, pp. 209-216 (in Italian).

18. Gardelli P.; Butyagin A. Stabiae, Villa Arianna. Relazione sulle due campagne di scavo e restauro 2012/2013 condotte dal Museo Statale Ermitage / Fondazione RAS. Rivista di Studi Pompeiani, XXIV, 2013. Roma, L’Erma di Bretschneider Publ., 2015, pp. 135-139 (in Italian).

19. Gardelli P.; Barker S. J.; Fant J. C. Resti pavimentali in opus sectile nel tepidarium e nel caldarium di Villa Arianna a Stabiae. Angelelli C.; Massara D.; Sposito F. (eds.). Atti del XXI Colloquio dell'Associazione Italiana per lo Studio e la Conservazione del Mosaico, Reggio Emilia, 18-21 marzo 2015. Tivoli, Edizioni Scripta Manent Publ., 2016, pp. 439-448 (in Italian). 
20. Gardelli P. History of the Excavations in the Area of the Great Peristyle of the Villa Arianna: $18^{\text {th }}$ Century Explorations to the Latest Investigations. Howe T. N.; Gleason K.; Sutherland J. (eds.). Excavation and Study of the Garden of the Great Peristyle of the Villa Arianna, Stabiae, 2007-2012. Quaderni di Studi Pompeiani, 7. Castellammare di Stabia, Nicola Longobardi Editore Publ., 2017, pp. 17-20.

21. Gardelli P.; Butyagin A. Villa Arianna, Stabiae: interventi di pulitura, scavo e restauro nell'ambiente 71 e nell'area esterna 73 condotti dal Museo Ermitage di San Pietroburgo. Rivista di Studi Pompeiani, XXIX, 2018. Roma, L'Erma di Bretschneider Publ., 2018, pp. 215-220 (in Italian).

22. Gardelli P.; Ariano C.; Butyagin A. Nuove acquisizioni sulle decorazioni musive di Villa Arianna a Stabia dai recenti scavi dell'ambiente 71. Atti del XXIV Colloquio dell'Associazione Italiana per lo Studio e la Conservazione del Mosaico, Este (Pd) 14-17 marzo 2018, Edizioni Quasar Publ., forthcoming (in Italian).

23. Giuffrè A. Sicurezza e Conservazione dei centri storici. Il caso Ortigia. Bari, Editori Laterza Publ., 1993. 279 p. (in Italian).

24. Gualandi M. Il mosaico dell'esedra con raffigurazione di negri. Cambi F.; Manacorda D. (eds.). Materiali per Populonia. Firenze, Edizioni all'Insegna del Giglio Publ., 2002, pp. 155-166 (in Italian).

25. Guidobaldi M. P. Villa Breglia e Villa Sora di Torre del Greco: problemi e prospettive. Newsletter di Archeologia C.I.S.A. - Centro Interdipartimentale di Servizi di Archeologia, 2015, vol. 6, pp. 107-128 (in Italian).

26. Guidobuoni E. (ed.). I terremoti prima del Mille in Italia e nell'area mediterranea: storia, archeologia, sismologia. Bologna, ING-SGA Publ., 1989. 765 p. (in Italian).

27. Haselberger L. Aspekte der Bauzeichnungen von Didyma. Revue Archéologique. Paris, Les Presses Universitaires de France Publ., 1991, pp. 99-113 (in German).

28. Hine H. M. The Date of the Campanian Earthquake. A.D. 62 or A.D. 63 or Both? LAAntiquité Classique, 1984, vol. 53, pp. 266-269.

29. Hine H. M. Rome, the Cosmos and the Emperor in Seneca's Natural Questions. The Journal of Roman Studies, vol. 96. London, Society for the Promotion of Roman Studies Publ., 2006, pp. 42-72.

30. Howe T. N.; Gardelli P. The Archaeological Park at Stabiae: A Regional Interdisciplinary and Sustainable Approach. Maltseva S. V.; Stanyukovich-Denisova E. Yu.; Zakharova A. V. (eds.). Actual Problems of Theory and History of Art: Collection of articles, vol. 5. St. Petersburg, NP-Print Publ., 2015, pp. 150-159. Available at: http://dx.doi.org/10.18688/aa155-1-14 (accessed 20 June 2019).

31. Jongman W. The Economy and Society of Pompeii. Amsterdam, J. C. Gieben Publ., 1988. 415 p.

32. Jacobelli L. I terremoti fra il 62 e il 79 d.C. nellarea vesuviana: le ragioni di un convegno. Fröhlich T.; Jacobelli L. (eds.). Archäologie und Seismologie: la regione vesuviana dal 62 al 79 d.C.: problemi archeologici e sismologici, Colloquium, Boscoreale, 26-27 November 1993. München, Biering \& Brinkmann Publ., 1995, pp. 17-21 (in Italian).

33. Lo Cascio E. La vita economica e sociale. Zevi F. (ed.). Pompei II. Napoli, Banco di Napoli Publ., 1992, pp. 113-131 (in Italian).

34. Lo Cascio E. Crescita e Declino. Studi di storia delleconomia romana. Roma, L'Erma di Bretschneider Publ., 2009. 386 p. (in Italian).

35. Lugli G. La tecnica edilizia romana con particolare riguardo a Roma e Lazio, 2 vols. Rome, G. Bardi Publ., 1957. 955 p. (in Italian).

36. Maiuri A. Lultima fase edilizia di Pompei. Roma, Instituto di Studi Romani Publ., 1942. 226 p. (in Italian).

37. Marturano A.; Rinaldis V. Il terremoto del 62 d.C.: un evento carico di responsabilità. Fröhlich T.; Jacobelli L. (eds.). Archäologie und Seismologie: la regione vesuviana dal 62 al 79 d.C.: problemi archeologici e sismologici, Colloquium, Boscoreale, 26-27 November 1993. München, Biering \& Brinkmann Publ., 1995, pp. 131-135 (in Italian).

38. Mastrodicasa S. Dissesti statici delle strutture edilizie. Diagnosi e consolidamento. Milano, Hoepli Publ., 1943. 973 p. (in Italian).

39. Meulemans L. G. Vivaria in doliis: A Cultural and Social Marker of of Romanised Society? Spataro M.; Villing A. (eds.). Ceramics, Cuisine and Culture: The Archaeology and Science of Kitchen Pottery in the Ancient Mediterranean World. Oxford, Oxbow Books Publ., 2015, pp. 170-178.

40. Nappo S. C. Villa Arianna: configurazione della villa verso il pianoro. Stabiae: storia e architettura: $250^{\circ}$ anniversario degli scavi di Stabiae 1749-1999. Roma, L'Erma di Bretschneider Publ., 2004, pp. 53-63 (in Italian).

41. Onorato G. O. La data del terremoto di Pompei. 5 febbraio 62 d. CR. Atti della Accademia Nazionale dei Lincei. Rendiconti. Classe di Scienze morali, storiche e filologiche, ser. VIII, 4, fasc. 11-12, 1949, pp. 664-661 (in Italian). 
42. Pagano M. Torre del Greco. Villa marittima romana in contrada Sora. Rivista di Studi Pompeiani, VI, 1993-1994. Roma, L'Erma di Bretschneider, 1996, pp. 267-269 (in Italian).

43. Pesando F. L'ultima fase edilizia di Pompei, sessanta anni dopo. Maiuri A. (ed.). L'ultima fase edilizia di Pompei. Napoli, Arte Tipografica Publ., 2002, pp. IX-XLI (in Italian).

44. Pisapia S. Ipotesi su alcune incongruenze tecniche nella Villa di San Marco a Stabiae. Fröhlich T.; Jacobelli L. (eds.). Archäologie und Seismologie: la regione vesuviana dal 62 al 79 d.C.: problemi archeologici e sismologici, Colloquium, Boscoreale, 26-27 November 1993. München, Biering \& Brinkmann Publ., 1995, pp. 115-117 (in Italian).

45. Renna E. La realtà sismologica dell'area vesuviana prima e dopo il 79 d.C. attraverso l'analisi delle fonti antiche. Fröhlich T.; Jacobelli L. (eds.). Archäologie und Seismologie: la regione vesuviana dal 62 al 79 d.C.: problemi archeologici e sismologici, Colloquium, Boscoreale, 26-27 November 1993. München, Biering \& Brinkmann Publ., 1995, pp. 195-199 (in Italian).

46. Ruggiero M. Degli Scavi di Stabia dal MDCCXLIX al MDCCLXXXII. Notizie raccolte e pubblicate da Michele Ruggiero. Napoli, M. de Rubertis Publ., 1881. 366 p. (in Italian).

47. Savino E. Nerone, Pompei e il terremoto del 63 d.C. Storchi Marino A.; Merola G. D. (eds.). Interventi imperiali in campo economico e sociale da Augusto al Tardoantico. Santo Spirito (Ba), Edipuglia Publ., 2009, pp. 225-244 (in Italian).

48. Sigurdsson H.; Carey S.; Cornell W.; Pescatore T. S. The Eruption of Vesuvius in A.D. 79. National Geographic Research, 1985, I, 3, pp. 332-387.

49. Varone A. Più terremoti a Pompei? I nuovi dati degli scavi di Via dell'Abbondanza. Fröhlich T.; Jacobelli L. (eds.). Archäologie und Seismologie: la regione vesuviana dal 62 al 79 d.C.: problemi archeologici e sismologici, Colloquium, Boscoreale, 26-27 November 1993. München, Biering \& Brinkmann Publ., 1995, pp. 29-35 (in Italian).

50. Varone A. Convivere con i terremoti. La travagliata ricostruzione di Pompei dopo il terremoto del 62 d.C. alla luce delle nuove scoperte. Mols S. T. A. M.; Moormann E. M. (eds.). Omni pede stare. Saggi architettonici e circumvesuviani in memoriam Jos de Waele. Studi della Soprintendenza archeologica di Pompei, 9. Napoli, Electa Publ., 2005, pp. 315-324 (in Italian).

Title. Reconstruction and Restoration Works at Villa Arianna in Stabia Prior to the Eruption of 79 A.D.

Author. Paolo Gardelli - Ph. D. student. Ludwig Maximilians Universität München, Institut für Klassische Archäologie, Katharina-von-Bora-Straße 10, 80333 München, Germany; executive coordinator and archaeologist. Restoring Ancient Stabiae Foundation, Via Solaro, 13, 80053 Castellammare di Stabia, Italy. pa.gardelli@gmail.com

Abstract. The entire Vesuvian region was hit by a seismic event of considerable intensity in 62 A.D. The news was reported by Tacitus and in more detail by Seneca. From the writings of Seneca it is clear that the urban centers most affected by the earthquake were Pompeii, Herculaneum, Nuceria and Neapolis.

It may seem strange that Stabiae is not mentioned on the list made by Seneca. The absence of explicit references should not be read as evidence of the absence of seismic activity in the Stabian area but should rather be understood as proof of the scarce attention paid by the ancient historiographers in the $1^{\text {st }}$ century A.D. to a modestly sized town like Stabiae.

Furthermore, despite the absence of explicit references in the written sources, other minor earthquakes may have continued to afflict Stabiae as well as the entire region after 62 A.D.

The excavation campaigns conducted at Villa Arianna in the last decade have provided the starting point and useful evidence for the discussion on the presence of reconstruction work within the housing complex, presumably resulting from the damage caused by seismic events preceding the eruption of 79 A.D.

Surprisingly, the $18^{\text {th }}$-century excavation reports are a good starting point. From a careful rereading of the excavation accounts, one can find valuable information about the discovery of objects, such as work tools typically used by masons and painters. Apparently, these objects seemed to the original excavators to be devoid of any value and were therefore destroyed or lost. Today, however, adopting a completely different methodological approach, these are of considerable importance for a more accurate understanding of Villa Arianna and of the reconstruction work in process. The archaeological evidence in situ and the data emerging during the excavation campaigns of recent years are even more abundant than those findings recorded in the $18^{\text {th }}$-century excavation reports.

The aim of the present study is to consolidate and summarize the archival data and the data from recent excavations. The picture which emerges from these observations is that of a residential complex, many parts of which were undergoing repair and restoration work in the years preceding the 79 A.D. eruption. 
These repair and restoration works almost never achieved the same level of artistry of the interior decoration of the Julio-Claudian and the early Neronian ages, but were very often carried out using lower quality materials and an inferior technique. Although the villas were being maintained, the standard was lower, possibly because, among other reasons, the owners were uncertain about future seismic activity - since earthquakes were a common occurrence over the entire area in the period between 62 and 79 A.D.

Keywords: Stabiae; Villa Arianna; otium Roman villas; 62 A.D. earthquake.

Название статьи. Работы по реконструкции и реставрации на вилле Ариадны в Стабиях до извержения 79 г. н. э.

Сведения об авторе. Гарделли Паоло - аспирант. Университет Людвига Максимилиана в Мюнхене, Институт классической археологии, Катарина-фон-Бора-штрассе, 10, 80333, Мюнхен, Германия; исполнительный координатор и археолог. Фонд реставрации древних Стабий, виа Соларо, 13, 80053, Кастелламмаре-ди-Стабия, Италия. pa.gardelli@gmail.com

Аннотация. Весь регион близ Везувия был затронут значительной сейсмической активностью в 62 г. н. э. Эти события донесены до нас Тацитом и более детально Сенекой. Из произведений Сенеки ясно, что наиболее пострадавшими от землетрясения городскими центрами были Помпеи, Геркуланум, Нуцерия и Неаполис. Может показаться странным, что Стабии не упомянуты Сенекой в этом перечне. Отсутствие ясных упоминаний не должно интерпретироваться как свидетельство отсутствия сейсмической активности в районе Стабий, но может служить доказательством слабого интереса историков I в. н. э. к такому небольшому городку, как Стабии.

Кроме того, несмотря на отсутствие ясных сообщений в письменных источниках, землетрясения меньшей силы могли затрагивать Стабии и весь регион в целом и после 62 г. н. э.

Археологические раскопки, которые проводились на вилле Ариадны на протяжении последнего десятилетия, обнаружили the starting point и важные свидетельства наличия работ по реконструкции на территории жилого комплекса, причиной которых, предположительно, являлась сейсмическая активность, предшествующая извержению 79 г. н. э.

Удивительно, но раскопки XVIII в. являются хорошей отправной точкой. Путем внимательного пересмотра археологических отчетов можно найти ценные сведения об обнаружении таких предметов, как инструменты, обычно использовавшиеся каменщиками и художниками. Очевидно, эти находки казались первооткрывателям лишенными всякой ценности и, следовательно, были утрачены или утеряны. Однако сегодня с использованием совсем иного методологического подхода эти предметы обладают значительной ценностью для более точного понимания виллы Ариадны и процесса реставрационных работ. Археологические свидетельства in situ и данные, появившиеся за время археологических работ на протяжении последних лет, более обильны, чем находки, упомянутые в археологических отчетах XVIII в.

Цель настоящего исследования - собрать воедино и проанализировать архивные данные и данные последних археологических сезонов. Панорама, складывающаяся из этих свидетельств, представляет нам жилой комплекс, многие части которого находились в состоянии укрепления и реставрационных работ в годы, предшествовавшие извержению 79 г. н. э. Эти работы почти никогда не достигают того художественного уровня декорации интерьера, какой был в период Юлиев-Клавдиев и в ранние годы правления Нерона, и очень часто в них использованы худшие по качеству материалы и более простые техники. Эти стандарты были ниже, несмотря на общий уровень поддержания виллы, в том числе изза того, что, возможно, владельцы были не уверены относительно будущей сейсмической активности, поскольку в период с 62 по 79 г. н. э. землетрясения случались довольно часто

Ключевые слова: Стабии, вилла Ариадны, римские морские виллы, землетрясение 62 г. н. э. 